\title{
Hemodynamic Forces Induce the Expression of Heme Oxygenase in Cultured Vascular Smooth Muscle Cells
}

\author{
Christopher T. Wagner, ${ }^{\star}$ William Durante, ${ }^{\S}$ Nick Christodoulides, ${ }^{\S}$ J. David Hellums, ${ }^{\star}$ and Andrew I. Schafer ${ }^{\ddagger \S}$ \\ *Cox Laboratory for Biomedical Engineering, Rice University, Houston, Texas 77251; ${ }^{\ddagger}$ Medical Service, Houston VA Medical Center, \\ and ${ }^{\S}$ Department of Medicine, "Department of Pharmacology, Baylor College of Medicine, Houston, Texas 77030
}

\begin{abstract}
Both nitric oxide (NO) and carbon monoxide (CO) are vessel wall-derived messenger molecules that cause platelet inhibition and vasodilation by activating guanylyl cyclase in target cells. Since vascular smooth muscle cells (SMCs) are exposed to shear and tensile stresses, this study examined the effects of these hemodynamic forces on the enzymes that generate NO and CO in SMCs. Monolayers of cultured rat aortic SMCs were subjected to shear stress using a modified cone and plate viscometer, or cyclic elongational stretch using a compliant silastic culture membrane. Shear stress stimulated time-dependent increases in mRNA and protein for inducible heme oxygenase-1 (HO-1), the enzyme which forms $\mathrm{CO}$ as a byproduct of heme degradation. The threshold level of shear necessary to induce HO-1 expression was between 5 and $10 \mathrm{dynes} / \mathrm{cm}^{2}$. In contrast, shear stress did not stimulate inducible NO synthase (iNOS) expression. Cyclic stretch also induced the expression of HO-1 but not of iNOS mRNA. Exposure of vascular SMCs to shear stress stimulated the production and release of $\mathrm{CO}$ as demonstrated by the $\mathrm{CO}$ dependent increase in intracellular cGMP levels in coincubated platelets. In addition, ADP-stimulated aggregation was inhibited in platelets exposed to sheared SMCs but not in platelets exposed to untreated control SMCs. Treatment of sheared SMCs with the HO-1 inhibitor, tin protoporphyrin-IX, blocked the antiaggregatory effect of the cells, whereas the iNOS inhibitor, methyl-L-arginine, had no effect. These results indicate that hemodynamic forces induce HO-1 gene expression and $\mathrm{CO}$ production in vascular SMCs, and that SMC-derived CO inhibits platelet aggregation. Thus, $\mathrm{CO}$ is a novel endogenous vessel wall-derived messenger molecule that may be selectively induced by hemodynamic forces to inhibit platelet reactivity and preserve blood fluidity at sites of vascular injury. (J. Clin. Invest. 1997. 100:589-596.) Key words: carbon monoxide - shear stress • cyclic stretch $\cdot$ gene regulation
\end{abstract}

\section{Introduction}

The passage of blood through the cardiovascular system generates hemodynamic forces. Fluid flow across the cell surface results in shear stress, while tensile stress, which produces elongational stretch, is caused by circumferential deformations

Address correspondence to Andrew I. Schafer, M.D., Department of Medicine, Baylor College of Medicine, 6550 Fannin, Suite 1425, Houston, TX 77030. Phone: 713-793-8300; FAX: 713-793-8333.

Received for publication 24 September 1996 and accepted in revised form 23 April 1997.

The Journal of Clinical Investigation

Volume 100, Number 3, August 1997, 589-596

http://www.jci.org resulting from transmural pressure gradients and vascular smooth muscle tone (1). These physical forces can alter the function of cells which comprise the vessel wall (2). Most studies of shear stress have examined its effect on endothelial cells which line the intimal surface of the vasculature. Shear stress induces elongation of endothelial cells in the direction of flow through cytoskeletal rearrangement $(3,4)$, inhibits cell proliferation (5), initiates intracellular signaling (6-9), and stimulates the synthesis and secretion of various bioactive molecules, including prostacyclin $\left(\mathrm{PGI}_{2}\right)$, tissue plasminogen activator, and platelet-derived growth factor (10-12). Most studies on the effects of stretch have likewise focused on endothelial cells, and have shown that it regulates endothelin-1 $(13,14), \mathrm{PGI}_{2}(13$, $15)$, tissue plasminogen activator $(13,16)$, and the proto-oncogenes c-fos and c-jun. (17). Investigations of the effect of strain on vascular smooth muscle cells have demonstrated that it induces the production of platelet-derived growth factor (18) and stimulates cell proliferation (19-21).

Increased levels of nitric oxide (NO) ${ }^{1}$ are also released by endothelial cells when stimulated by shear stress (22-24) or cyclic strain (25). NO is a simple diatomic gas which is formed as a byproduct of the conversion of L-arginine to L-citrulline by NO synthases (NOS) (26). In the circulation, the production of NO by vascular cells promotes blood flow by inhibiting smooth muscle contraction and platelet adhesion and aggregation (27). These effects of NO are mediated by the activation of soluble guanylyl cyclase and the consequent rise in guanosine $3^{\prime}, 5^{\prime}$-cyclic monophosphate (cGMP) in vascular smooth muscle cells (SMCs) and platelets (28). While endothelial cells continually release small amounts of NO through a constitutive isoform of NOS, SMCs express an inducible isotype, termed inducible NOS (iNOS), which is capable of synthesizing large quantities of NO (29).

A second diatomic gas molecule, carbon monoxide $(\mathrm{CO})$, which is produced as a byproduct of heme catabolism to biliverdin by heme oxygenase (HO), has many of the same properties as NO. It stimulates the production of cGMP by interacting with the heme moiety of guanylyl cyclase (30). Like NO, $\mathrm{CO}$ causes blood vessel relaxation and platelet inhibition through a cGMP-dependent mechanism $(31,32)$. We have reported recently that vascular SMCs express two isoforms of $\mathrm{HO}$, an inducible form (HO-1) and a constitutive form ( $\mathrm{HO}-2)$ (33). HO-1 is induced by its substrate, heme, as well as other diverse stimuli, including metal-containing compounds such as sodium arsenite (NaAs) $(34,35)$.

SMCs are continually exposed to cyclic strain due to pulsatile blood flow. Vascular circumferential elongation under nor-

1. Abbreviations used in this paper: $\mathrm{CO}$, carbon monoxide; $\mathrm{HO}$, heme oxygenase; L-NMA, $N^{\mathrm{G}}$-methyl-L-arginine; NaAs, sodium arsenite; NO, nitric oxide; NOS, nitric oxide synthase; SMC, smooth muscle cell; SNP, sodium nitroprusside; SnPP-IX, tin protoporphyrin-IX; SSRE, shear stress response element. 
mal physiologic conditions at peak systole ranges between 2 and $18 \%$ depending on the vessel of interest $(36,37)$. However, elongation for a particular vessel may be slightly larger in hypertensive states (38). SMCs are also directly exposed to blood flow and shear stress at sites of vascular damage caused by the rupture of atherosclerotic lesions or invasive techniques such as balloon angioplasty. Furthermore, interstitial fluid flow from the blood stream to the tunica media transmits shear stress to SMCs even in intact blood vessels. Theoretical calculations of the shear stress levels induced by this fluid flow have predicted SMC exposure to shear stress levels of 2-3 dynes/ $\mathrm{cm}^{2}$, with further elevated levels under pathophysiological conditions $(39,40)$. SMCs stimulated by different humoral mediators are capable of producing $\mathrm{NO}$ and $\mathrm{CO}$ through activation of iNOS and HO-1, respectively, and both gases inhibit platelet aggregation and smooth muscle contraction by activating soluble guanylyl cyclase. In this study we determined whether physiologically relevant hemodynamic forces induce iNOS and/or HO-1 expression, leading to the production of platelet inhibitory $\mathrm{NO}$ and/or CO by vascular SMCs. Induction of these enzymes and the subsequent release of guanylyl cyclase-stimulatory gases by hemodynamic forces could potentially modulate vascular tone and platelet reactivity, thereby regulating blood fluidity at sites of vascular damage.

\section{Methods}

Materials. Adenosine diphosphate (ADP), cycloheximide, fibrillar type I collagen, guanidine isothiocyanate (GITC), sarkosyl, sodium dodecyl sulfate (SDS), sodium nitroprusside (SNP), $\beta$-mercaptoethanol, trichloroacetic acid, $N^{\mathrm{G}}$-methyl-L-arginine (L-NMA), bovine serum albumin, $N$-tris[hydroxymethyl]methyl-2-aminoethane sulfonic acid (TES) and $N$-2-hydroxyethylpiperazine- $N^{\prime}$-2-ethane sulfonic acid (Hepes) buffers, ethyleneglycol-bis- $N, N^{\prime}$-tetraacetic acid (EGTA), minimal essential media, and NaAS were purchased from Sigma Chemical Co. (St. Louis, MO). Fetal calf serum (FCS), cell culture trypsin, penicillin, streptomycin, and neomycin were purchased from GIBCO BRL (Gaithersburg, MD). Recombinant murine interleukin$1 \beta$ (IL-1 $\beta$ ) was purchased from R\&D Systems (Minneapolis, MN). Tin protoporphyrin-IX (SnPP-IX) was purchased from Porphyrin Products, Inc. (Logan, UT). Actinomycin D was purchased from Boehringer Mannheim (Indianapolis, IN). [ $\left.{ }^{32} \mathrm{P}\right] \mathrm{UTP}$ was purchased from Amersham Corp. (Arlington Heights, IL). HO-1 polyclonal antibody from rabbit was purchased from StressGen Biotech Corp. (Victoria, Canada). iNOS monoclonal antibody from mouse was purchased from Transduction Laboratories (Lexington, KY). Silastic membrane $\left(0.05^{\prime \prime}\right.$ thick) was purchased from SF Medical (Hudson, MA).

SMC culture. Rat aortic SMCs were provided by Dr. Tim ScottBurden at the University of Texas in Houston. They were isolated from rat thoracic aorta using standard enzymatic digestion methods and characterized as described elsewhere (41). Stock cells were passaged and grown in minimum essential media supplemented with $10 \%$ (vol/vol) heat-inactivated FCS, $4 \mathrm{mM}$ glutamine, $50 \mathrm{mg} / \mathrm{liter}$ penicillin, $50 \mathrm{mg} /$ liter streptomycin, $100 \mathrm{mg} /$ liter neomycin, $2 \mathrm{mM}$ TES, and $2 \mathrm{mM}$ Hepes. Cells to be used in experiments were seeded on glass plates for exposure to shear stress or compliant silastic membranes for exposure to cyclic strain. The surfaces were precoated with collagen type I at $\sim 15 \mu \mathrm{g}$ collagen $/ \mathrm{cm}^{2}$ and allowed to grow to confluence. Collagen solutions were prepared from insoluble fibrillar type I collagen dissolved in 3\% glacial acetic acid, homogenized, with impurities separated by centrifugation. Collagen concentration was determined by hydroxyproline assay, described elsewhere (42).

Shear stress experimental conditions. Before treatment, SMCs were placed on serum-free media (same as above with $0.1 \%$ bovine serum albumin instead of $10 \%$ FCS) for $12 \mathrm{~h}$. The cells were then sheared in a modified cone and plate viscometer using a $1^{\circ}$ cone (Ferranti Electric, Inc., Commack, NY). Cultures were maintained at $37^{\circ} \mathrm{C}$ by heating from below with a circulating water bath, and the atmosphere was regulated with humidified $5 \% \mathrm{CO}_{2} /$ air mixture during the experiment. This system is similar to that used by Dewey and his colleagues to study shear stress effects on cultured endothelial cells. Unsheared control plates were treated for $24 \mathrm{~h}$ with serum-free media only as a negative control, and with $\mathrm{NaAs}(10 \mu \mathrm{M})$ to induce HO-1 expression or IL-1 $\beta(5 \mathrm{ng} / \mathrm{ml})$ to induce iNOS expression as positive controls. SnPP-IX $(30 \mu \mathrm{M})$ was used to inhibit HO-1 and was added $1.5 \mathrm{~h}$ before the end of treatment while L-NMA $(1 \mathrm{mM})$ was added for the entire treatment period to inhibit iNOS.

Cyclic strain experimental conditions. The cells, grown on a taut silastic membrane, were treated with serum-free media for $24 \mathrm{~h}$ as described above. The stretch apparatus is similar to that used by Carosi et al. (43). Briefly, the membrane is fixed at one end with the other attached to a piston which passes through the culture chamber wall. The piston is repeatedly pulled by a mechanical device on which the frequency and stroke distance can be set. A motion control apparatus is set up in parallel in which the membrane is attached to a ridged frame. The frame is connected to the piston but the other end is free to move, providing a control for the movement of media induced by the sliding piston. Confluent monolayers of SMC were stretched at a $10 \%$ level for up to $24 \mathrm{~h}$ at 60 cycles/min $(1 \mathrm{~Hz})$.

$m R N A$ analysis. Total cellular RNA was prepared by scrape-harvesting the SMCs into GITC solution (4 M GITC, $25 \mathrm{mM}$ sodium citrate, $5 \%$ sarkosyl, pH 7.0) containing $0.1 \mathrm{M} \beta$-mercaptoethanol. RNA was isolated by centrifugation through a $5.7 \mathrm{M}$ cesium chloride cushion at $100,000 \mathrm{~g}$ for $22 \mathrm{~h}$. The RNA pellet was washed, precipitated overnight, and resuspended in Tris-EDTA buffer (10 mM Tris$\mathrm{HCl}, 1 \mathrm{mM}$ EDTA, $\mathrm{pH}$ 7.6). RNA concentration was determined by absorbance spectrophotometry at $260 \mathrm{~nm}$.

mRNA for iNOS and HO-1 was detected by RNase protection assay using a commercially available kit from Ambion Inc. (Austin, TX). cDNA probe templates for both HO-1 (285 bp) and iNOS (160 bp) were produced from total rat SMC RNA by reverse transcriptionpolymerase chain reaction using primers based on published sequences for the two genes $(44,45)$. The antisense RNA probe was generated in the presence of $\left[{ }^{32} \mathrm{P}\right] \mathrm{UTP}$ by in vitro transcription. Total RNA $(10-15 \mu \mathrm{g})$ was hybridized with $2-4 \times 10^{5} \mathrm{cpm}$ of the riboprobe, and the protection assay was performed according to the procedure outlined in the kit manual. The labeled RNA was separated on a $6 \%$ acrylamide/ $8 \mathrm{M}$ urea denaturing polyacrylamide gel. The gel was dried and exposed to x-ray film at $-70^{\circ} \mathrm{C}$ in the presence of intensifying screens. The size of the predicted nucleotide-protected fragments was confirmed by using a ${ }^{32}$ P-labeled RNA ladder.

Protein analysis. Cellular protein was prepared by scrape-harvesting SMCs into cold phosphate-buffered saline (PBS). The cells were centrifuged at $2,000 \mathrm{~g}$ for $2 \mathrm{~min}$, and the pellet was resuspended in cell sample buffer (12 mM Tris-HCl, $\mathrm{pH} 6.8,5 \%$ glycerol, and $0.4 \%$ SDS), boiled for $10 \mathrm{~min}$, sonicated in a water bath for $15 \mathrm{~min}$, and then centrifuged at $10,000 \mathrm{~g}$ for $10 \mathrm{~min}$. The supernatant was saved, and protein concentrations were determined using the bicinchoninic acid protein assay by Pierce Chemical Co. (Rockford, IL).

Cell protein extracts were separated by polyacrylamide gel electrophoresis under reducing conditions using separation gels of $20 \%$ acrylamide for HO- 1 and $10 \%$ for iNOS. The proteins were transferred to nitrocellulose membranes and detected using an enhanced chemiluminescence Western blotting kit from Amersham Corp. After blocking with $5 \%$ nonfat milk, HO-1 was detected using a polyclonal antibody at a 1:500 dilution. iNOS was detected using a primary monoclonal antibody at a 1:2,500 dilution. Horseradish peroxidase-conjugated secondary antibodies were used at 1:7,500 and 1:5,000 dilution for HO-1 and iNOS, respectively, and the bands were visualized after exposure to photographic film.

Platelet detector system. Human platelets were isolated from whole blood anticoagulated with 1:7 acid citrate dextrose (ACD, NIH 
Formula A) drawn from healthy donors. The platelets were washed in Tyrode's buffer $\left(137 \mathrm{mM} \mathrm{NaCl}, 2.8 \mathrm{mM} \mathrm{KCl}, 0.42 \mathrm{mM} \mathrm{NaH}_{2} \mathrm{PO}_{4}\right.$, and $12 \mathrm{mM} \mathrm{NaHCO}$ ), and finally a washed platelet suspension containing $2.5 \times 10^{8}$ platelets $/ \mathrm{ml}$ was prepared in JNL buffer $(6 \mathrm{mM}$ dextrose, $130 \mathrm{mM} \mathrm{NaCl}, 9 \mathrm{mM} \mathrm{NaHCO}, 10 \mathrm{mM}$ sodium citrate, $10 \mathrm{mM}$ Tris base, $3 \mathrm{mM} \mathrm{KCl}, 2 \mathrm{mM}$ Hepes, and $0.9 \mathrm{mM} \mathrm{MgCl}_{2}$ ). The medium was aspirated from SMCs which had been treated and washed twice with PBS to remove inducers and inhibitors which might affect the platelets. The SMCs were then overlaid with $3 \mathrm{ml}$ of platelet suspension $\left(\sim 1.5 \times 10^{7}\right.$ platelets $\left./ \mathrm{cm}^{2}\right)$ and allowed to coincubate for $5 \mathrm{~min}$. The platelets were removed from the cell monolayers and added to an equivalent volume of trichloroacetic acid (6\% final concentration). The platelet-acid suspensions were sonicated and assayed for cGMP using a commercially available radioimmunoassay kit (DuPont NEN, Boston, MA). To control for variability in platelet responsiveness between experiments, a separate platelet sample from each experiment was exposed to the guanylyl cyclase activator SNP (50 $\mu \mathrm{M}$ for $5 \mathrm{~min}$ ), and results were expressed as a percentage of SNPinduced cGMP elevation. We have previously used increases in cGMP levels in platelets treated in this manner to indicate the production of CO by SMCs (33).

In some experiments, washed rat platelets were isolated from ACD anticoagulated rat whole blood. Platelet-rich plasma was obtained by centrifugation at $110 \mathrm{~g}$ for $20 \mathrm{~min}$ followed by $10 \mathrm{~min}$ at $1,800 \mathrm{~g}$ to pellet the platelets. The pellet was resuspended in Tyrode's buffer supplemented with $0.35 \%$ (wt/vol) bovine albumin $(\mathrm{pH} 6.6$ with $\mathrm{HCl}$ ) and $0.5 \mathrm{mM}$ EGTA. The platelets were again pelleted, and the final platelet suspension was prepared in JNL buffer.

Platelet aggregation analysis. Washed platelet suspensions were prepared as above and treated for $1 \mathrm{~h}$ with $100 \mu \mathrm{M}$ aspirin. After aspirating the media, SMCs were washed twice with PBS and then overlaid with the platelet suspension and coincubated for $5 \mathrm{~min}$. The platelets were removed and placed in an aggregometer and checked for their ability to aggregate in response to $10 \mu \mathrm{M}$ ADP. Aggregometry tracings were recorded by computer, and the level of aggregation was corroborated using particle counting, checking both pre- and post-aggregated suspensions.

Statistical analysis. Results are expressed as the means \pm SEM. Significant difference between means was computed using a paired Student's $t$ test with significance defined as $P<0.05$.

\section{Results}

Exposure of SMCs to a shear stress of 20 dynes $/ \mathrm{cm}^{2}$ induced the expression of HO-1 mRNA (Fig. $1 A$ ). HO-1 mRNA expression was observed as early as $1 \mathrm{~h}$ after the onset of shear stress, and HO-1 message progressively increased over a period of $24 \mathrm{~h}$ (Fig. $1 A$ ). In contrast, shear stress failed to induce iNOS mRNA expression in SMCs (Fig. $1 A$ ). In control experiments, treatment of SMCs with a known inducer of HO-1 $(\mathrm{NaAs} ; 10 \mu \mathrm{M})$ or iNOS (IL-1 $; 5 \mathrm{ng} / \mathrm{ml})$ for $24 \mathrm{~h}$ under nonshear conditions stimulated HO-1 and iNOS mRNA expression, respectively (Fig. $1 A$ ). Similarly, exposure of SMCs to $10 \%$ stretch at 60 cycles/min $(1 \mathrm{~Hz})$ induced HO-1 mRNA expression without inducing iNOS (Fig. $1 \mathrm{~B}$ ). Motion control experiments performed in parallel failed to induce either $\mathrm{HO}-1$ or iNOS mRNA expression (Fig. $1 B$ ).

The induction of HO-1 mRNA expression by shear stress was dependent on the magnitude of shear stress. A threshold level between 5 and 10 dynes $/ \mathrm{cm}^{2}$ was required to induce $\mathrm{HO}-1$ mRNA levels, and higher levels of shear stress further increased the amount of HO-1 message (Fig. 2). In all instances, the level of $\beta$-actin mRNA remained constant, confirming equal loading of RNA (Fig. $1 A$ and Fig. 2).

Shear stress $\left(20\right.$ dynes $\left./ \mathrm{cm}^{2}\right)$ also increased the amount of
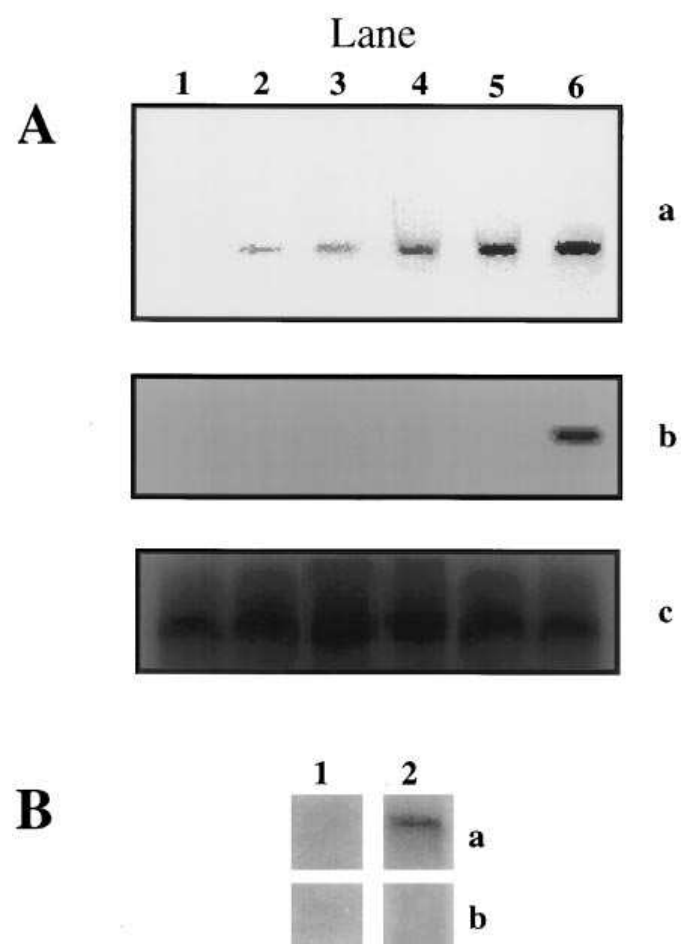

Figure 1. (A) Time course of shear stress induction of HO-1 and iNOS mRNA. Confluent monolayers of SMCs were exposed to a shear stress of 20 dynes $/ \mathrm{cm}^{2}$ for $0.5,1,2,4$, and $24 \mathrm{~h}$ (lanes $1-5$ ). The cells were harvested and total RNA prepared as described in Methods. RNase protection analysis was performed for HO-1 (a), iNOS $(b)$, and $\beta$-actin (c). Lane 6 is a positive control for HO- 1 expression $(10 \mu \mathrm{M} N a A s$ for $24 \mathrm{~h}$ under nonshear conditions in $a$ ) and iNOS expression ( $5 \mathrm{ng} / \mathrm{ml} \mathrm{IL}-1 \beta$ for $24 \mathrm{~h}$ under nonshear conditions in $b$ ). $\beta$-Actin control panel shows equivalent loading of RNA. (B) Cyclic strain induction of HO-1 and iNOS mRNA. Confluent monolayers of SMC were exposed to motion control (lane 1) or cyclic strain (lane 2) for $24 \mathrm{~h}$. mRNA was analyzed for the presence of HO-1 ( $a$ ) and iNOS $(b)$.

HO-1 protein in SMCs without inducing iNOS protein expression (Fig. 3). The shear-mediated increase in HO-1 protein was dependent on the length of shear exposure, with a maximal increase observed after $24 \mathrm{~h}$ of stimulation (Fig. 3). Treatment of SMCs with actinomycin D $(2 \mu \mathrm{g} / \mathrm{ml})$ or cycloheximide $(5 \mu \mathrm{g} / \mathrm{ml})$ blocked shear-induced HO-1 mRNA and protein expression, respectively (data not shown).

To examine the relative induction of HO-1 by cyclic strain compared to fluid dynamic shear stress, SMC responses to these two hemodynamic mechanisms were examined simultaneously. Fig. $4 A$ shows the induction of HO- 1 protein stimulated by exposure of SMCs to shear stress of $20 \mathrm{dynes} / \mathrm{cm}^{2}$ for $24 \mathrm{~h}$, and to cyclic strain of $10 \%$ at $1 \mathrm{~Hz}$ for $24 \mathrm{~h}$. The magnitude of protein expression is 4.7 -fold greater in the shearinduced SMCs than in the stretch-induced SMCs, as determined by densitometry (Fig. $4 \mathrm{~B}$ ).

In subsequent experiments, $\mathrm{HO}$ activity was measured by monitoring SMC CO production. Since CO is a readily diffusible membrane-soluble gas which is known to activate soluble guanylyl cyclase $(30,32)$, $\mathrm{HO}$ activity was determined by measuring the intracellular concentration of cGMP in coincubated 


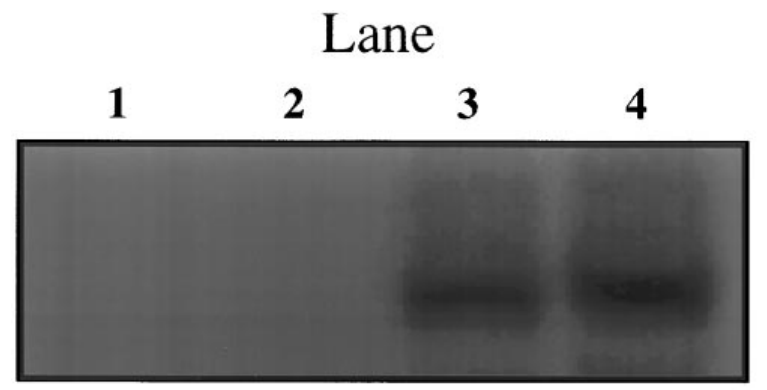

A

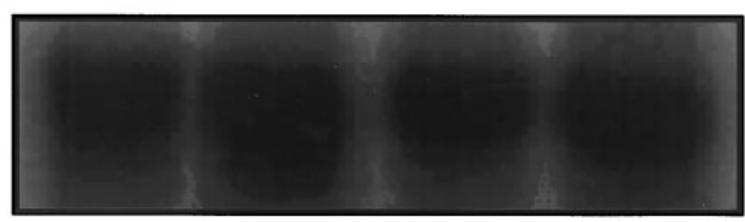

B

Figure 2. HO-1 mRNA induction by different levels of shear stress. Confluent monolayers of SMCs exposed to 5, 10, and 20 dynes $/ \mathrm{cm}^{2}$ for $24 \mathrm{~h}$ (lanes 2-4) were compared to a stationary control (lane 1) by RNase protection assay for HO-1 mRNA. $A$ shows HO-1 mRNA expression at 10 and 20 dynes $/ \mathrm{cm}^{2}$ but not at 5 dynes $/ \mathrm{cm}^{2}$. $B$ shows $\beta$-actin control for RNA loading.

detector platelets. Incubating platelets with SMCs which had been exposed to shear stress (20 dynes/ $\mathrm{cm}^{2}$ for $6 \mathrm{~h}$ ) significantly increased platelet cGMP concentration compared to control unsheared SMCs (Fig. 5). Similarily, incubation of platelets with NaAs- $(10 \mu \mathrm{M}$ for $24 \mathrm{~h})$ or IL-1 $\beta$-treated $(5 \mathrm{ng} / \mathrm{ml}$ for $24 \mathrm{~h}$ ) but unsheared SMCs also elevated platelet cGMP levels (Fig. 5). Recovery of platelets after incubation with SMCs averaged $\sim 82 \%$ under all conditions: $82.4 \pm 3.9 \%$ for untreated, $79.9 \pm 1.2 \%$ for IL- $1 \beta$-treated, $84.3 \pm 2.6 \%$ for NaAs-treated, and $82.2 \pm 3.3 \%$ for shear-treated SMCs. The stimulatory effect on platelet cGMP concentration by either shear or NaAstreated SMCs was blocked by incubating the SMCs with the HO-1 inhibitor, SnPP-IX $(30 \mu \mathrm{M})$. In contrast, treatment of SMCs with the iNOS inhibitor, L-NMA $(1 \mathrm{mM})$, did not inhibit the elevation of platelet cGMP induced by shear, and

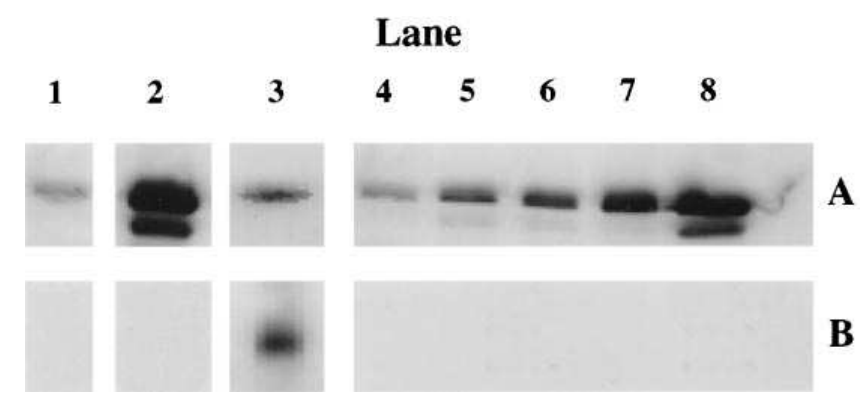

Figure 3. Time course of shear stress induced HO-1 $(A)$ and iNOS $(B)$ protein expression. Confluent monolayers of SMCs were exposed to a shear stress of 20 dynes $/ \mathrm{cm}^{2}$ for $1,2,4,6$, and $24 \mathrm{~h}$ (lanes 4-8). Controls for HO-1 and iNOS protein expression were SMCs treated with serum-free media (lane 1), $10 \mu \mathrm{M} \mathrm{NaAs}$ (lane 2), and $5 \mathrm{ng} / \mathrm{ml}$ IL-1 $\beta$ (lane 3 ) for $24 \mathrm{~h}$ under nonshear conditions. Total cell protein in both panels was prepared as described in Methods.

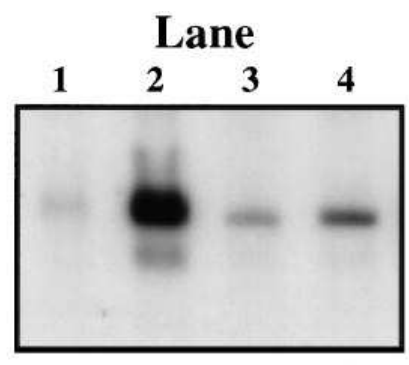

A

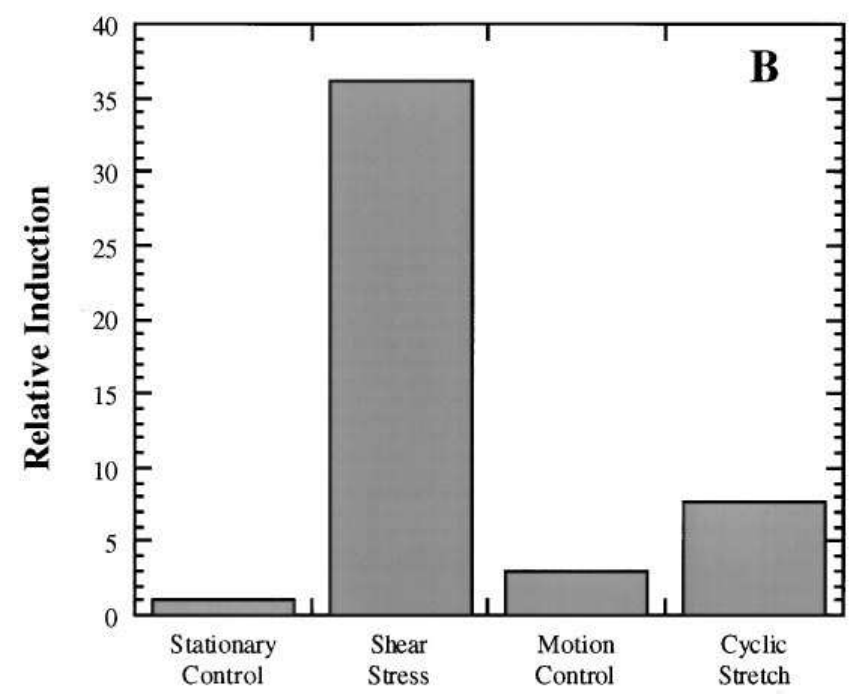

Figure 4. Relative induction of HO-1 expression by cyclic strain and shear stress. $A$ shows HO-1 protein expression detected by Western blot. Rat aorta SMCs of the same passage were simultaneously stimulated by either 20 dynes $/ \mathrm{cm}^{2}$ shear stress for $24 \mathrm{~h}$ (lane 2) or $10 \% \mathrm{cy}$ clic strain at $1 \mathrm{~Hz}$ for $24 \mathrm{~h}$ (lane 4$)$. Stationary control (lane 1 ) and motion control (lane 3 ) samples are also shown. $B$ shows the relative induction of HO-1 determined by densitometry of the Western blot shown in $A$.

caused only a slight decrease in NaAs-treated SMCs (Fig. 5). However, either L-NMA $(1 \mathrm{mM})$ or SnPP-IX $(30 \mu \mathrm{M})$ partially reversed the stimulatory effect on platelet cGMP evoked by IL-1 $\beta$-treated SMCs (Fig. 5). The combined addition of L-NMA $(1 \mathrm{mM})$ and SnPP-IX $(30 \mu \mathrm{M})$ to IL-1 $\beta$-treated SMCs completely inhibited the stimulatory effect on platelet cGMP levels (data not shown).

To examine the potential scavenging effect of hemoglobin on $\mathrm{CO}$ released from SMCs, experiments were performed using platelets in whole blood instead of washed suspensions in the platelet detector system. In these experiments, cGMP was measured in platelet-rich plasma prepared from whole blood after exposure to SMCs. Although there was a consistent and reproducible increase in platelet cGMP levels from whole blood exposed to shear stress-stimulated SMCs $\left(20\right.$ dynes $/ \mathrm{cm}^{2}$ for $24 \mathrm{~h}$ ), the increase was not statistically significant (data not shown).

Additional experiments were performed to determine if the results of these platelet-SMC interactions were a function of species differences (human platelets and rat SMCs). Rat platelet suspensions were therefore used in coincubation ex- 


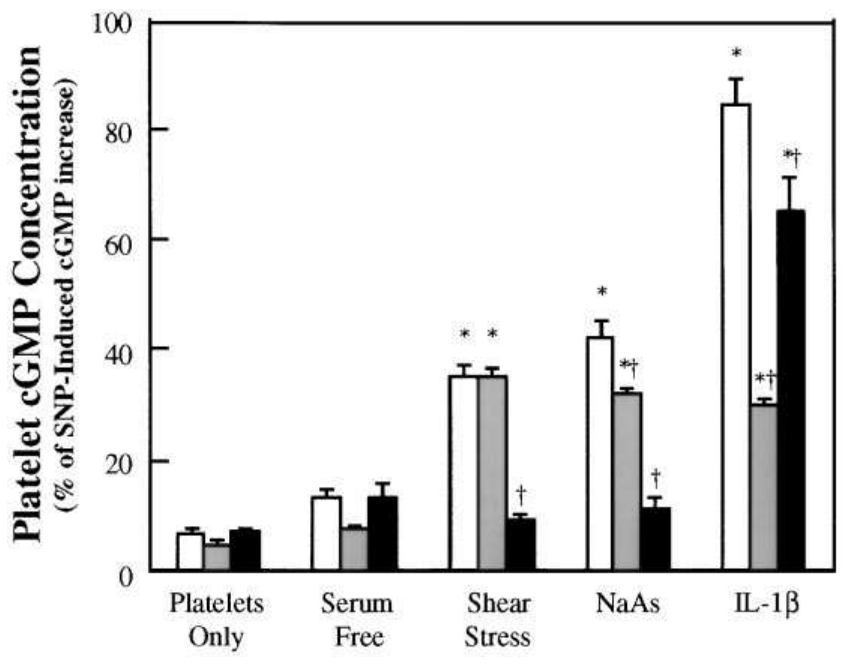

Figure 5. cGMP levels in detector platelets exposed to SMCs. SMCs treated with serum-free media, $5 \mathrm{ng} / \mathrm{ml}$ IL- $1 \beta, 10 \mu \mathrm{M} \mathrm{NaAs}$ for $24 \mathrm{~h}$, or $6 \mathrm{~h}$ of exposure to shear stress at 20 dynes $/ \mathrm{cm}^{2}$, were coincubated for $5 \mathrm{~min}$ with washed platelet suspensions. $\mathrm{NO}$ and $\mathrm{CO}$ production from the SMCs were detected by increased levels of cGMP in the platelets. Washed platelets which had not been exposed to any stimulus were analyzed to determine the basal level of cGMP, and platelets treated with $50 \mu \mathrm{M}$ SNP were used to determine the maximum level of cGMP attainable for each suspension. All treatments were performed either in the absence of inhibitors (open bars), with $1 \mathrm{mM}$ L-NMA (shaded bars), or $30 \mu \mathrm{M}$ SnPP-IX (solid bars). *Significant elevation in cGMP in response to treatment over serum-free negative control $(P<0.01)$. 'Significant inhibitor-mediated reduction in cGMP levels $(P<0.05) . n=4-6$.

periments with rat aortic SMCs exposed to shear stress. Elevations in rat platelet cGMP levels were observed to be comparable and consistent with the increases demonstrated in human platelet suspensions (data not shown).

Finally, the ability of shear stress to stimulate the production of a platelet-inhibitory substance by vascular SMCs was examined. ADP $(10 \mu \mathrm{M})$ produced a submaximal and irreversible aggregation of aspirin-treated platelets within $3 \mathrm{~min}$ (Fig. 6). Coincubation of platelets with untreated control SMCs minimally affected platelet aggregation in response to ADP (Fig. 6). Coincubation of platelets with SMCs which had been exposed to shear stress (20 dynes $/ \mathrm{cm}^{2}$ for $6 \mathrm{~h}$ ) inhibited ADP-induced platelet aggregation. Likewise, NaAs- $(10 \mu \mathrm{M}$ for $24 \mathrm{~h}$ ) or IL-1 $\beta$-treated $(5 \mathrm{ng} / \mathrm{ml}$ for $24 \mathrm{~h}$ ) but unsheared SMCs blocked platelet aggregation in response to ADP (Fig. 6). Finally, coincubation of sheared or NaAs-treated SMCs with the HO-1 inhibitor, SnPP-IX $(30 \mu \mathrm{M})$, reversed the antiaggregatory effect of the SMCs (Fig. $6 \mathrm{~A}$ ). In contrast, the iNOS inhibitor, L-NMA $(1 \mathrm{mM})$, reversed the platelet inhibitory effect of only IL-1 $\beta$-stimulated, but not shear-stimulated SMCs (Fig. 6 B).

\section{Discussion}

Flow-induced vasodilation is thought to be mediated principally through $\mathrm{PGI}_{2}$ and NO (46-48). Both shear stress (11, 22, $49)$ and cyclic strain $(25,43)$ induce the production of these two autocoids from endothelial cells. This study demonstrates
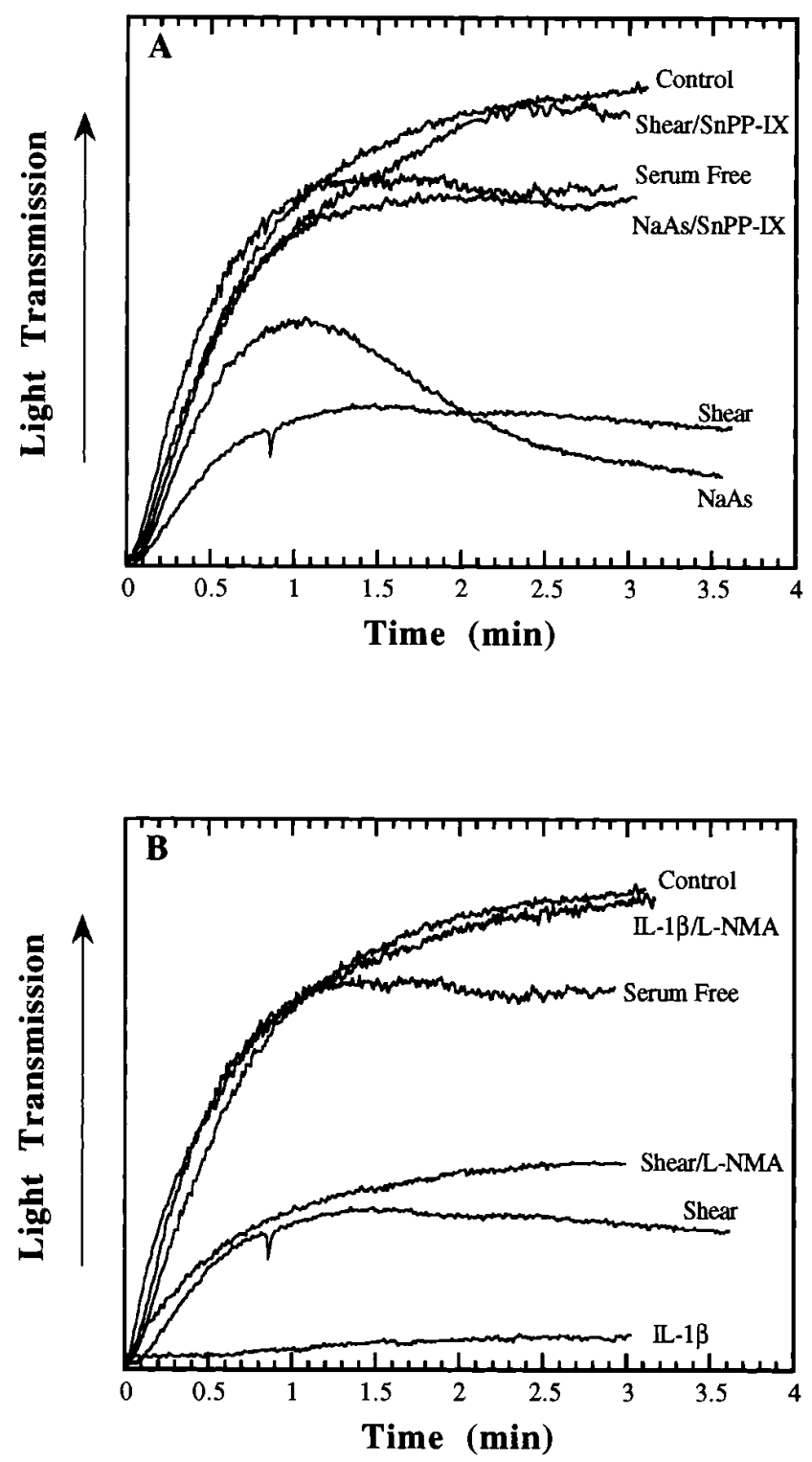

Figure 6. Platelet inhibition by shear-induced CO from SMCs. Washed platelets were coincubated for $5 \mathrm{~min}$ with SMCs treated with serum-free media, IL-1 $\beta(5 \mathrm{ng} / \mathrm{ml})$, or NaAs $(10 \mu \mathrm{M})$ for $24 \mathrm{~h}$ or SMCs exposed to 20 dynes $/ \mathrm{cm}^{2}$ shear stress for $6 \mathrm{~h}$. In some experiments, SnPP-IX $(30 \mu \mathrm{M})$ was added to the SMCs $1.5 \mathrm{~h}$ before coincubation with platelets $(A)$. In other experiments, L-NMA $(1 \mathrm{mM})$ was added for the entire treatment period $(B)$. The SMCs were treated for $1 \mathrm{~h}$ with $100 \mu \mathrm{M}$ aspirin to inhibit prostacyclin production. After coincubation, the platelets were placed in an aggregometer and stimulated with $10 \mu \mathrm{M}$ ADP. A control curve of ADP-induced aggregation in platelets not exposed to SMCs is also shown. This figure is representative of three independent experiments.

that the physiologically relevant hemodynamic forces, shear stress and cyclic strain, selectively induce the expression of HO-1 in SMCs which may contribute to flow-induced vasodilation through the production of the novel mediator $\mathrm{CO}$ (31).

Shear stress-induced HO-1 gene expression is dependent on de novo RNA and protein synthesis and is associated with the release of a biologically active substance, presumably $\mathrm{CO}$, 
which activates guanylyl cyclase in platelets and inhibits ADPstimulated platelet aggregation. In addition, the induction of SMC CO release by shear stress and cyclic strain is specific to gaseous autocoid production since these forces failed to induce iNOS gene expression. The effects of cyclic strain were specific for this hemodynamic stimulus since parallel motion controls failed to induce HO-1 mRNA expression.

The molecular mechanism by which shear stress and cyclic strain regulate gene expression is not well understood. Cyclic strain may be sensed through integrin connections to the extracellular matrix since soluble Arg-Gly-Glu peptides have been shown to block SMC PDGF production by stretch (50). Recently, a 6-bp sequence, GAGACC, was determined to be a shear stress response element (SSRE) in the promoter of several genes responsive to shear stress (51). The SSRE may be the binding site for transcription factors activated by shear stress. In particular, Resnick et al. (52) showed that shear stress activates nuclear factor- $\kappa \mathrm{B}$ in endothelial cells and that this nuclear factor specifically binds to the SSRE. Interestingly, based on the published sequence, the HO-1 promoter possesses an SSRE (53); however, we cannot definitively conclude that signaling occurs through this SSRE in shear-activated SMCs since genes lacking this SSRE have been shown to be induced by shear stress. Shyy et al. demonstrated that a cisacting phorbol ester (TPA)-responsive element not containing the above sequence was necessary for shear stress induction of monocyte chemotactic protein-1 (54).

$\mathrm{HO}-1$ is known to be activated by alterations in temperature and is classified as a heat-shock protein (34). The temperature of the media in the plates during shear stress exposure was maintained at $37^{\circ} \mathrm{C}$ with a circulating water bath below the plate. The temperature was monitored and remained between 36.8 and $37.2^{\circ} \mathrm{C}$ throughout the period of shear. Stretching experiments were performed inside a cell culture incubator maintained at $37^{\circ} \mathrm{C}$. Thus, it is unlikely that the observed induction of HO-1 is a heat-shock response.

Vascular SMCs can be exposed to shear stress levels of at least 20 dynes $/ \mathrm{cm}^{2}$ when directly exposed to blood flow after deep vessel-wall injury. However, even SMCs within the intact vessel wall are exposed directly to flow (and wall shear stress) driven by the transmural pressure gradient (39). Fluid movement through the interstitial spaces of the intact vessel wall, which continually provides nutrients to the surrounding tissue (55), generates shear stress in a manner similar to blood flow through vessels. Because the transmural pressure gradient is relatively low, the potentially important effects of shear stress on SMCs have been largely ignored in the past. Calculations indicate that SMCs are likely to be exposed to shear stress levels as high as 2-3 dynes $/ \mathrm{cm}^{2}$ in intact blood vessels (39). However, changes in hydraulic conductivity across the endothelial cell lining and pathologic conditions resulting in elevations of blood pressure will dramatically increase the shear stress exerted on the SMCs. We have demonstrated that shear stress levels approaching these magnitudes are capable of inducing HO-1 gene expression. Thus, shear stress-mediated induction of HO-1 expression and CO release by vascular SMCs may be a physiologically relevant response which is not limited to pathophysiologic situations of direct SMC exposure to blood flow after injury.

Similarly, circumferential stretch as a result of pulsatile flow is sensed continuously by the vascular wall, with levels ranging from 2 to $18 \%(36,37)$, and individual vessels may have larger strains than normal in hypertensive states (38). The expression of HO-1 induced by (patho)physiologic levels of stretch studied here may be a process by which to decrease intraluminal pressures through vasodilation. Thus, both shear stress- and cyclic strain-induced HO-1 expression may play a role in maintaining vascular tone.

A previously described platelet detection system was used to detect CO released from SMCs (33). Elevated levels of platelet cGMP were observed when platelets were coincubated with SMCs previously exposed to shear stress. The failure of shear stress to upregulate iNOS indicated that NO release was unlikely to contribute to the increased platelet cGMP levels under these conditions. Furthermore, the specific iNOS inhibitor, L-NMA, did not block the rise in platelet cGMP evoked by SMCs exposed to shear stress. In contrast, the HO-1 inhibitor SnPP-IX inhibited the stimulatory effect on platelet cGMP concentration induced by sheared SMCs. (Similarly, SnPP-IX was able to eliminate the increase in platelet cGMP levels induced by SMC exposed to the HO-1 inducer, NaAs.) These results indicate that only HO-1 is induced by shear stress, and that SMC-derived CO elevates cGMP levels in coincubated platelets.

Incubation of platelets with IL-1 $\beta$-treated SMCs also increased platelet cGMP levels. The NOS inhibitor, L-NMA, only partially blocked this effect, suggesting that in addition to NO other guanylyl cyclase-stimulatory mediators may be involved. In this regard, our Western blotting experiments demonstrated that IL-1 $\beta$ also stimulates HO-1 protein expression, confirming a recent study that showed that IL-1 $\beta$ induces the transcriptional activation of the HO-1 gene in vascular SMC (56), and suggesting that SMC CO release may be involved. Our finding that the combined addition of L-NMA and SnPP-IX completely reversed the elevation in cGMP levels in platelets coincubated with IL-1 $\beta$-treated SMCs is consistent with this observation and indicates that cytokine-treated SMCs are capable of increasing platelet cGMP concentration via the simultaneous release of $\mathrm{CO}$ and $\mathrm{NO}$.

Although the increase in platelet cGMP levels was dampened when red blood cells (RBCs) were included in the coincubation, they were still consistently elevated. The observed reduction in whole blood is presumably due to the binding of $\mathrm{CO}$ to hemoglobin. The precise physiologic impact of $\mathrm{CO}$ scavenging by hemoglobin is unknown since platelets tend to be localized in flowing blood at the periphery of the vessel, displaced from the center by the mass of RBCs (57). Therefore platelets in contact with the vessel wall in vivo may be more affected by $\mathrm{CO}$ (and NO) than this in vitro study suggests. Furthermore, modulation of vascular tone by the abluminal release of $\mathrm{CO}$ in response to shear and stretch would not be dampened by RBCs and hemoglobin.

The potential physiological relevance of shear stress-induced HO-1 gene expression was demonstrated by the capacity of endogenously released CO to inhibit platelet aggregation. Incubation of platelets with sheared SMCs blocked ADP-stimulated platelet aggregation. This antiaggregatory effect was not mediated by prostacyclin, since SMC cyclooxygenase was inhibited by aspirin before the experiment. L-NMA completely reversed the platelet inhibitory effects of IL-1 $\beta$-treated SMCs, indicating that SMC-derived NO mediates the antiaggregatory effect under these conditions. However, the inhibition of platelet aggregation by sheared SMCs was prevented by treating the SMCs with SnPP-IX but not with L-NMA, indicating that 
only CO released by sheared SMCs mediates platelet inhibition. This is consistent with earlier studies showing that exogenously added $\mathrm{CO}$ inhibits platelet aggregation, and indicates that $\mathrm{CO}$ is of potential physiological importance as a regulator of platelet reactivity (32).

In conclusion, we have demonstrated that hemodynamic forces induce the expression of HO-1. Normal arterial levels of shear stress selectively induce $\mathrm{HO}-1$ gene expression and $\mathrm{CO}$ production in vascular SMCs. Even though the actions and putative physiologic roles of $\mathrm{CO}$ are similar to those of NO, the induction of HO-1 by shear stress and cyclic strain in SMCs does not appear to be a redundant regulatory mechanism since iNOS was not induced under the same conditions. In addition, this study demonstrates that SMCs exposed to shear stress can inhibit platelet aggregation via the release of $\mathrm{CO}$. Thus, $\mathrm{CO}$ released endogenously from vascular cells exposed to physiologically and pathophysiologically relevant hemodynamic forces may represent a novel messenger molecule that modulates the state of blood fluidity in the circulation.

\section{Acknowledgments}

The authors would like to thank Kelly J. Peyton, Janet K. Hrbolich, and Lan Liao for their help with this study.

This work was supported in part by National Institutes of Health grants 5 R37 HL18584, 5 R50 NS 23327, and HL 36045, a Veterans Affairs Merit Review Board grant, and a grant-in-aid from the American Heart Association, Texas Affiliate.

\section{References}

1. Patrick, C.W., and L.V. McIntire. 1995. Shear stress and cyclic strain modulation of gene expression in vascular endothelial cells. Blood Purif. 13: $112-124$

2. Kroll, M.H., J.D. Hellums, L.V. McIntire, A.I. Schafer, and J.L. Moake. 1996. Platelets and shear stress. Blood. 85:1525-1541.

3. Dewey, C.F., S.R. Bussolari, M.A. Gimbrone, and P.F. Davies. 1981. The dynamic response of vascular endothelial cells to fluid shear stress. J. Biomech. Eng. 103:177-185.

4. Wechezak, A.R., R.F. Vigger, and L.R. Sauvage. 1985. Fibronectin and F-actin redistribution in cultured endothelial cells exposed to shear stress. Lab. Invest. 53:639-647.

5. Ando, J., H. Nomura, and A. Kamiya. 1987. The effects of fluid shear stress on the migration and proliferation of cultured endothelial cells. Microvasc. Res. 33:62-70.

6. Olesen, S.P., D.E. Clapham, and P.F. Davies. 1987. Hemodynamic shear stress activates a $\mathrm{K}^{+}$current in vascular endothelial cells. Nature (Lond.). 331: 168-170.

7. Mo, M., S.G. Eskin, and W.P. Schilling. 1991. Flow-induced changes in $\mathrm{Ca}^{2+}$ signaling of vascular endothelial cells: effect of shear stress and ADP. Am. J. Physiol. 260:H1698-H1707.

8. Nollert, M.U., S.G. Eskin, and L.V. McIntire. 1990. Shear stress increases inositol trisphosphate levels in human endothelial cells. Biochem. Biophys. Res. Commun. 10:281-287.

9. Patrick, C.W., and L.V. McIntire. 1995. Fluid shear stress effects on endothelial cell cytosolic pH. Tissue Eng. 1:53-70.

10. Mitsumata, M., R.S. Fishel, R.M. Nerem, R.W. Alexander, B.C. Berk. 1993. Fluid shear stress stimulates platelet-derived growth factor expression in endothelial cells. Am. J. Physiol. 265:H3-H8.

11. Frangos, J.A., L.V. McIntire, S.G. Eskin, and C.L. Ives. 1985. Flow effects on prostacyclin production by cultured human endothelial cells. Science (Wash. DC). 227:1477-1479.

12. Diamond, S.L., S.G. Eskin, and L.V. McIntire. 1989. Fluid flow stimulates tissue plasminogen activator secretion by cultured endothelial cells. Science (Wash. DC). 243:1483-1485.

13. Carosi, J.A., and L.V. McIntire. 1994. Modulation of secretion of vasoactive materials from human an bovine endothelial cells by cyclic strain. Biotechnol. Bioeng. 43:615-621.

14. Wang, D.L., C.C. Tang, B.S. Wung, H.H. Chen, M.S. Hung, and J.J. Wang. 1993. Cyclical strain increases endothelin-1 secretion and gene expression in human endothelial cells. Biochem. Biophys. Res. Commun. 195:10501056.
15. Sumpio, B.E., and A.J. Banes. 1988. Prostacyclin synthetic activity in cultured aortic endothelial cells undergoing cyclic mechanical deformation. Surgery (St. Louis). 104:383-389.

16. Iba, T., and B.E. Sumpio. 1992. Tissue plasminogen activator expression in endothelial cells exposed to cyclic strain in vitro. Cell Transplant. 1:43-50.

17. Du, W., W. Xu, and B.E. Sumpio. 1993. Proto-oncogenes c-fos, c-jun, and transcription factors AP-1 and NF-kB are activated in endothelial cells (EC) exposed to cyclic strain. FASEB (Fed. Am. Soc. Exp. Biol.) J. 7:A2. (Abstr.)

18. Wilson, E., Q. Mai, K. Sudhir, R.H. Weiss, and H.E. Ives. 1993. Mechanical strain induces growth of vascular smooth muscle cells via autocrine action of PDGF. J. Cell Biol. 123:741-747.

19. Birukov, V.G., V.P. Shirinsky, O.V. Stepanova, V.A. Tkachuk, A.W. Hahn, T.J. Resink, and V.N. Smirnov. 1995. Stretch affects phenotype and proliferation of vascular smooth muscle cells. Mol. Cell. Biochem. 144:131-139.

20. Hishikawa, K., T. Nakaki, T. Marumo, M. Hayashi, H. Suzuki, R. Kato, and T. Suruta. 1994. Pressure promotes DNA synthesis in rat cultured vascular smooth muscle cells. J. Clin. Invest. 93:1975-1980.

21. Yang, Z., G. Noll, and T.F. Luscher. 1993. Calcium antagonists differently inhibit proliferation of human coronary smooth muscle cells in response to pulsatile stretch and platelet-derived growth factor. Circulation. 88:832-836.

22. Nishida, K., D.G. Harrison, J.P. Navas, A.A. Fisher, S.P. Dockery, M. Uematsu, R.M. Nerem, R.W. Alexander, and T.J. Murphy. 1992. Molecular cloning and characterization of the constitutive bovine aortic endothelial cell nitric oxide synthase. J. Clin. Invest. 90:2092-2096.

23. Rubanyi, G.M., J.C. Romero, and P.M. Vanhoutte. 1986. Flow-induced release of endothelium-derived relaxing factor. Am. J. Physiol. 250:H1145-H1149.

24. Ranja, V., Z. Xiao, and S.L. Diamond. 1995. Constitutive NOS expression in cultured endothelial cells is elevated by fluid shear stress. Am. J. Physiol. 269:H550-H555.

25. Awolesi, M.A., W.C. Sessa, and B.E. Sumpio. 1995. Cyclic strain upregulates nitric oxide synthase in cultured bovine aortic endothelial cells. J. Clin. Invest. 96:1449-1454.

26. Palmer, R.M.J., A.S. Ashton, and S. Moncada. 1988. Vascular endothelial cells synthesize nitric oxide from L-arginine. Nature (Lond.). 333:664-666.

27. Moncada, S., and A. Higgs. 1993. The L-arginine-nitric oxide pathway. N. Engl. J. Med. 329:2002-2012.

28. Stamler, J.S., D.J. Single, and J. Loscalzo. 1992. Biochemistry of nitric oxide and its redox-activated forms. Science (Wash. DC). 258:1898-1902.

29. Busse, R., and A. Mulsch. 1990. Induction of nitric oxide synthase by cytokines in vascular smooth muscle cells. FEBS Lett. 275:87-90.

30. Ramos, K.S., H. Lin, and J.J. McGrath. 1989. Modulation of cyclic guanosine monophosphate levels in cultured smooth muscle cells by carbon monoxide. Biochem. Pharmacol. 38:1368-1370.

31. Graser, T., Y.P. Vedernikov, and D.S. Li. 1990. Study on the mechanism of carbon monoxide induced endothelium-independent relaxation in porcine coronary artery and vein. Biomed. Biochim. Acta. 49:293-296.

32. Brüne, B., and V. Ullrich. 1987. Inhibition of platelet aggregation by carbon monoxide is mediated by activation of guanylate cyclase. Mol. Pharmacol. 32:497-504.

33. Christodoulides, N., W. Durante, M.H. Kroll, and A.I. Schafer. 1995. Vascular smooth muscle cell heme oxygenases generate guanylyl cyclase-stimulatory carbon monoxide. Circulation. 91:2306-2309.

34. Maines, M.D. 1988. Heme oxygenase: function, multiplicity, regulatory mechanisms and clinical applications. FASEB (Fed. Am. Soc. Exp. Biol.) J. 2: 2557-2568.

35. Sunderman, F.W. 1987. Metal induction of heme oxygenase. Ann. NY Acad. Sci. 514:65-80.

36. Dobrin, P.B. 1978. Mechanical properties of arteries. Physiol. Rev. 58: 397-460.

37. Bergel, D.H. 1961. The static elastic properties of the arterial wall. J. Physiol. 156:445-447.

38. Patel, D.H., J.C. Greenfield, W.G. Austin, A.G. Morrow, and D.L. Fry 1965. Pressure-flow relationships in the ascending aorta and femoral artery of man. J. Appl. Physiol. 20:459-463.

39. Wang, D.M., and J.M. Tarbell. 1995. Modeling interstitial flow in an artery wall allows estimation of wall shear stress on smooth muscle cells. J. Biomech. Eng. 117:358-363.

40. Alshihabi, S., Y. Chang, Z. Huang, D. Wang, J. Frangos, and J. Tarbell. 1994. How does interstitial fluid flow affect smooth muscle cells in the arterial wall? Adv. Bioeng. 28:327-328.

41. Scott-Burden, T., T.J. Resink, U. Baur, M. Burgin, and F.R. Buhler 1989. Epidermal growth factor responsiveness in smooth muscle cells from hypertensive and normotensive rats. Hypertension (Dallas). 13:295-304.

42. Burgman, I., and R. Loxley. 1963. Two improved and simplified methods for the spectrophotometric determination of hydroxyproline. Anal. Chem. 35:1960-1965

43. Carosi, J.A., S.G. Eskin, and L.V. McIntire. 1992. Cyclic strain effects on the production of vasoactive materials in endothelial cells. J. Cell. Physiol. 151:29-36.

44. Lyons, C.R., G.J. Orloff, and J.M. Cunningham. 1991. Molecular cloning and functional expression of an inducible nitric oxide synthase from a murine macrophage cell line. J. Biol. Chem. 267:6370-6374. 
45. Shibahara, S., R. Müller, H. Taguchi, and T. Yoshida. 1985. Cloning and expression of cDNA for rat heme oxygenase. Proc. Natl. Acad. Sci. USA. 82: 7865-7869.

46. Koller, A., D. Sun, and G. Galey. 1993. Role of shear stress and endothelial prostaglandins in flow- and viscosity-induced dilation of arterioles in vitro. Circ. Res. 72:1276-1284.

47. Pohl, U., K. Herlan, A. Huang, and E. Bassenge. 1991. EDRF-mediated shear-induced dilation opposes myogenic vasoconstriction in small rabbit arteries. Am. J. Physiol. 261:H2016-H2023.

48. Kuo, L., W.M. Chilian, and M.J. Davis. 1991. Interaction of pressureand flow-induced responses in porcine coronary resistant vessels. Am. J. Physiol. 261:H1706-H1715.

49. Buga, G.M., M.E. Gold, J.M. Fukuto, and L.G. Ignarro. 1991. Shear stress-induced release of nitric oxide from endothelial cells grown on beads. Hypertension (Dallas). 17:187-193.

50. Wilson, E., K. Sudhir, and H.E. Ives. 1995. Mechanical strain of rat vascular smooth muscle cells is sensed by specific extracellular matrix/integrin interactions. J. Clin. Invest. 96:2364-2372.

51. Resnick, N., T. Collins, W. Atkinson, D.T. Bonthron, C.F. Dewey, and M.A. Gimbrone. 1993. Platelet-derived growth factor B chain promoter con- tains a cis-acting fluid shear-stress-responsive element. Proc. Natl. Acad. Sci. USA. 90:4591-4595.

52. Resnick, N., and M.A. Gimbrone. 1995. Hemodynamic forces are complex regulators of endothelial gene expression. FASEB (Fed. Am. Soc. Exp. Biol.) J. 9:874-882.

53. Alam, J., J. Cai, and A. Smith. 1994. Isolation and characterization of the mouse heme oxygenase-1 gene. J. Biol. Chem. 269:1001-1009.

54. Shyy, J.Y.J., M.-C. Lin, J. Han, Y. Lu, M. Petrime, and S. Chien. 1995. The cis-acting phorbol ester "12-O-tetradecanoylphorbol 13-acetate"-responsive element is involved in shear stress-induced monocyte chemotactic protein 1 gene expression. Proc. Natl. Acad. Sci. USA. 92:8069-8073.

55. Kim, W.S., and J.M. Tarbell. 1994. Macromolecular transport through the deformable porous media of an artery wall. J. Biomech. Eng. 116:156-163.

56. Yet, S.-F., A. Pellacani, C. Patterson, L. Tan, S.C. Folta, L. Foster, W.-S Lee, C.-M. Hsieh, and M.A. Perella. 1997. Induction of heme oxygenase-1 expression in vascular smooth muscle cells: a link to endotoxic shock. J. Biol. Chem. 272:4295-4301.

57. Goldsmith, H.L., and V.T. Turitto. 1986. Rheological aspects of thrombosis and haemostasis: basic principles and applications. Thromb. Haemostasis. $55: 415-435$ 